This is the Author's Copy of:

Lewis, Jamie and Thomas, Julia. (2017). 'From Trading Zones to Buffer Zones: Art and Metaphor in the Communication of Psychiatric Genetics to Publics.' In Reyes-Galindo, L and Duarte, T. (eds). Intercultural Communication and Science and Technology Studies. Palgrave MacMillan 


\title{
From Trading Zones to Buffer Zones: Art and Metaphor in the Communication of Psychiatric Genetics to Publics
}

\section{Jamie T. Lewis and Julia M. Thomas, Cardiff University}

\begin{abstract}
Psychiatric genetics has a difficult relationship with the public given its unshakeable connection to eugenics. Drawing from a five-year public engagement programme that emerged from an internationally renowned psychiatric genetics centre, we propose the concept of the Buffer Zone to consider how an exchange of viewpoints between groups of people - including psychiatric geneticists and lay publics - who are often uneasy in one another's company can be facilitated through the use of art and metaphor. The artwork at the exhibitions provided the necessary socio-cultural context for scientific endeavours, whilst also enabled public groups to be part of, and remain in, the conversation. Crucial to stress is that this mitigation was not to protect the science; it was to protect the discussion.
\end{abstract}

\section{Introduction}

'Scientific communication' is often conceptualised as scientists conveying scientific information to various publics or lay groups (Gregory and Miller 1998; Rowe and Frewer 2005; Holliman et al. 2009; Davies and Horst 2017). This is notoriously a difficult task to accomplish well (Bennett and Jennings 2011). Scientific specialisms consist of esoteric knowledge and vernaculars that are at some remove from everyday life and talk. When the science in question is psychiatric genetics, though, there are added 'communication' barriers 
to overcome such as the field's problematic socio and political history (Lewis and Bartlett 2015). Compared to other branches of genetics, for example, the specialism is much maligned; it has had to contend with past failures, false promises (Joseph 2006) and, historically, has a difficult relationship with the public given its unshakeable connection to eugenics (Kerr and Shakespeare 2002). This backdrop is said to continue to hang over the field like Damocles'sword (Propping 2005), despite today’s promising laboratory developments (Stoltenberg and Burmeister 2000; Burmeister et al. 2008).

Psychiatric genetics' public groups, including those with direct experience of mental health conditions, are multifaceted. Differences include their socio-demographics, their relationship to and experience of the psychiatric profession, and the way in which they receive, and offer in return, information about conditions that are contested, stigmatised, and potentially distressing. The reception of scientific information and their responses can therefore be unpredictable and divergent, which means that forms of communication and those who communicate them need to be creative and flexible. Science communication as a form of public engagement is not a passive, static activity. It is a dynamic, ever-changing and ongoing process (Lewis et al. 2017). In this chapter, we use our public engagement arts initiative that ran from 2011 to 2015 as a case study to reflect on the ways in which scientific information about the genetic contribution of psychiatric conditions is relayed by scientists to various non-scientific groups. Linked to an internationally renowned laboratory researching the biological underpinnings of psychiatric conditions, which we call The Centre, our programme of events engaged a general, non-scientific public, people diagnosed with a mental illness, people with a particular interest in mental health, medical students, schoolchildren and representatives from within artistic disciplines and communities. 
Although art and science initiatives like ours have become more commonplace, psychiatric genetics may resist an alignment with the arts for fear of being perceived as less scientific by its peer disciplines. Also problematic is the desire by scientists to communicate scientific facts and to provide unambiguous and objective answers. This can be seen as going against the grain of an artistic approach more concerned with provoking questions and evoking multiple subjective interpretations and reactions (Costache 2012).

It has also been put that "artworks inspire, illustrate and communicate knowledge, but they do not produce it" (Garneau 2008, p. 27). However, the arts can facilitate the production of knowledge through their strong connections with the discursive groups and communities that surround, make sense of, and apply science. Furthermore, the arts can encourage a questioning approach, exploring the ethical ramifications of developments in knowledge, as well as providing a social commentary on scientific practices. In this respect, engagement through the arts can provide the necessary socio-cultural context for scientific endeavours, whilst also enabling public groups to be part of, and remain in, the conversation. We therefore reflect on the value of art as a method of participatory engagement with science, especially when the science is controversial and highly emotive, like psychiatric genetics.

\section{Communicating Science: Disciplines and Trading Zones}

Today, more than ever, science is a complex and corrugated map, partitioned into various territories and sub territories (Gieryn 1999). Most commonly, these colonies are identified as disciplines (biology, sociology etc.), although others talk of epistemic cultures (Knorr Cetina 1999), or communities of practice (Lave and Wenger 1991). These divisions are not a mirror on the nature they seek to explain; they are not natural kinds that can map exactly to 
phenomena in the world (Lewis et al. 2016), nor are they pure breeds (Galison 2010). Rather, their making takes considerable effort as over time they are landscaped, shaped, and accomplished by those inhabiting the space. In this regard, disciplines have both practical and symbolic functions.

Practically, disciplines promote specialisation, provide a home for particular forms of techniques and practices, nurture particular ways of thinking and seeing the world (see Fleck 1935 on thought collectives, or Hacking 1994 on styles of reasoning) and constitute the modern social order of academic knowledge (Weingart and Stehr 2000). Symbolically, disciplines help to characterise experts as cognisant, providing them with the epistemic capital to speak authoritatively over certain matters. But whilst, for example, medics have a stake on the understandings of the human brain, so too do biologists, psychologists, sociologists, and even artists. To this end, most agree that there is some form of hierarchy of esteem in academic scientific disciplines and, ever since a burgeoning science began to splinter and fragment, each specialism has gone through its own struggle for recognition (Rheinberger 2016). Physics has often been positioned at the peak of the academic pyramid, followed by the other hard sciences of chemistry and biology, and these are separated from the softer, human sciences such as psychology, geography and sociology (Storer 1967; Cole 1983; Pinar et al. 2008), which are themselves considered to be kept apart from the more artistic and literary subjects. This is not to say the human sciences or artistic subjects are subordinate to the 'harder' life sciences, or that they are necessarily less authoritative on matters, but that their internal disciplinary integrity is not as strong (Holmwood 2010), their methods not as standardised, their shared practice languages not as uniform, and their coherence not as secured. ${ }^{1}$ 
Each of these scientific collectives also has its own specialised language, its own concepts and neologisms - often tacitly understood by its members - and rarely has too much in common with other specialisms (see Galison 1997; Collins 2011; Duarte 2013). Disciplinary borders therefore have very real effects for those who find themselves inside and outside the boundary, for those who walk on the verges, and for those who seek to find ways of travelling between the territorial lands. All told, whilst Rheinberger (2016, p. 173) claims that the "significance of rigidly fixed disciplines has waned", the map of science has created distinctive affinities that are much more than just surface-level differences in subject matter. Significantly, scientists are also socialised into the values of their disciplinary communities, the result of which means that the wandering scientist faces a considerable amount of reorientation, re-evaluation, and negotiation when she travels across disciplinary borders, making the task of doing interstitial work a formidable one (Lewis et al. 2016). This is what Galison and Stump (1996) refer to as the 'problem of disunity', and resolving the ways in which knowledge and those that produce it can travel between different fields of enquiry, despite deep-rooted linguistic (and cultural) differences, has been one of the main focuses of Science and Technology Studies (STS) (Galison 2010; Reyes-Galindo 2014).

Nonetheless, nowadays, working between and across disciplines is seen as a good in the academy (Strathern 2006). So, how do scientists from apparently incommensurable and unconnected epistemes work together? Galison (1997) has provided us with one possible conceptual toolkit to understand interdisciplinary and interlinguistic communication. He proposes the metaphor of Trading Zones to show how interdisciplinary communication and exchange is accomplished within science. The very idea of trading often supposes an underlying notion of capital (Galison 2010). Anthropology, though, where work on the practices of trade has been assiduously explored, has shown how there is no universal 
currency of exchange. Groups of people can trade even if they attribute different meanings to that which is circulated. And, yet, as Marcel Mauss ([1969, p. 31] 1925) wrote in the early $20^{\text {th }}$ century, "objects are never completely separated from the [wo]men who exchange them; the communion and alliance they establish are well-nigh indissoluble". For Galison (1997, p. 783), who uses physics as an example, a similar, and yet different, arrangement is true in science. He points to the way that "two groups can agree on rules of exchange even if they ascribe utterly different significance to the objects being exchanged; they may even disagree on the meaning of the exchange process itself. Nonetheless, the trading partners can hammer out a local coordination, despite vast global differences". It is therefore in these metaphorical Trading zones, according to Galison, where objects are exchanged, ideas are shared, interdisciplinary work instigated and interstitial languages formed. "What is exchange work today", Galison (2010, p. 33) continues, "may well become the disciplinary pillars of tomorrow: science is forever in flux, not just in its results but [also] in the contours of its disciplines".

However, science communication is not solely a matter of scientist-to-scientist interaction and exchange. Historically, one of the more impassable borders in the communication of science is between science and the non-scientific public who are faced with a torrent of technical scientific terms. Indeed, the languages of science are said to be incongruous with normal, everyday speak. Despite this, scientists are expected to communicate, and to engage with the general public. It is, as Gregory and Miller (1998, p. 1) state, as if "scientists have been delivered a new commandment from on high: thou shall communicate" the work of science to the masses ${ }^{2}$. Of course, when we consider science communication, we talk of science multiple as we speak of publics plural. When scientists - the travelling disciples spreading the scientific word - communicate their work to the public they are presenting 
much more than just their own views and values, and yet they rarely talk for the whole of science. They represent, instead, the view of their particular disciplinary specialism or collective (see Horst 2013) .

In what follows, we consider the particular scientific specialism of psychiatric genetics. As an intellectual field, psychiatric genetics is rather promiscuous, appropriating ideas from both psychiatry and genetics, as well as other fields of enquiry, in order to try to identify the genetic mechanisms underlying susceptibility to common psychiatric conditions such as Schizophrenia and Bipolar Disorder ${ }^{4}$. We report on a five-year public engagement programme that emerged out of The Centre and use it to reflect on the ways in which psychiatric genetics engages and encounters different public groups within the topic of current developments in mental health (and genetics). Specifically, we examine several public engagement arts events and activities that endeavoured to provide both physical and metaphorical space for various publics and experts to come together in conversation about the mind and mental health. Such roaming between disciplines like art and science can instigate an unsettling, a disturbance that can encourage each disciplinary specialism to look with new eyes at their own familiar, and possibly taken for granted perspective.

Drawing on Galison's Trading Zone concept for describing interdisciplinary communication, we propose the concept of the Buffer Zone: an adaptive space resulting in behavioural dispositions that enable conversations about mental health and genetics between experts from various disciplinary hinterlands and publics to begin and continue. The Buffer Zone affords members from each collective the freedom to broach issues openly; it helps flatten hierarchy, resists jargon and protects the discussion of potentially sensitive and threatening topic areas from being aborted early because of conversational conflict. Developing artistic public 
engagement opportunities within this Buffer Zone framework nurtures the ideal of an uninhibited platform for encounters and conversations between people with different perspectives on mental health. This encourages an inclusive, dialogical, but questioning engagement with developments in psychiatric genetics. Important to STS is to state that to buffer is not to de-value expertise (Collins and Evans 2007), but is to recognise the ways in which artistic works can illuminate alternative matters of concern (see Holmberg and Ideland 2016), and allow these matters to be raised and diversify but, most importantly, to be conserved.

\section{The Art of Science; The Science of Art}

Gregory and Miller (1998) remark that $20^{\text {th }}$ century champions of science complained that science in popular culture was an underling to other intellectual practices such as literature and art. The culture and education of science, and its initial post-war neglect of the public, had alienated and distanced many people from the practice (Wynne 1992a). This, they claim, was embittered, in part, because the custodians of contemporary culture had been trained in subjects other than science. They cite Charles Percy Snow's 1959 Rede lecture, which condemned the UK's education system for over-valuing literary and artistic skills at the expense of scientific pursuits as a defining moment. Snow's (1959) now (in)famous 'two cultures' watchword described how he believed fences had been built separating and distancing the two terrains from one another to the point that they had almost nothing in common (Collins 2014). Few travellers crossed over to the other territory since the two cultures were considered impervious to one another. Snow was not the first (nor the last) to describe the dichotomous relationship between artistic endeavours and scientific pursuits, but his public profile brought the debate to public prominence (Collini 1993). 
In 'Two Cultures - And a second look', Snow (1963) took a more optimistic tone, suggesting that a 'third culture' would emerge that would bridge the gap between scientists and literary scholars. This space - or metaphorical Trading Zone - consisted of so-named 'social historians', such as sociologists, economists, and historians who were on speaking terms with both scientists and artists (see Shaffer 1998). These boundary crawlers could shuttle between the cultures, instigating conversations, trading ideas and initiating dialogue. For the most part, though, Snow's positioning of the sciences and the arts as two poles has been criticised to the point that this dichotomous relationship has now become somewhat of a trope. ${ }^{5}$ Hall (1999) discusses how framing knowledge production in binary terms, such as between science and art, can simply serve to entrap us. This entrapment undermines the need to focus on a more general and powerful willingness to question any claims to knowledge irrespective of their disciplinary roots.

Notwithstanding the criticism of the 'two cultures' allegory, much work is still required if one wishes to bridge scientific and artistic worlds. Some of the tensions between art and science arise from differences in, what Collins and Evans (2007) describe as, their formative intention in relation to interpretative ambiguity: unlike many contemporary artists, scientists do not explicitly intend to produce ambiguous communications from their discipline. Indeed, many scientists advocate scientific clarity and regard science as a route to some underlying truth through a systematic, analytical approach (Popper 1994) ${ }^{6}$. This scientific attitude often extends into how science should be communicated. Societal scientific literacy can be achieved, so the deficit model tells us, if leading scientists recite top-down accounts about truths, facts and statistics clearly and authoritatively to an uneducated and ignorant public (The Royal Society 1985, see also Wilsdon and Willis (2004) for criticisms of PUS' failings 
on Genetically Modified crops and Bovine Spongiform Encephalopathy) ${ }^{7}$. Artists, on the other hand, are not necessarily interested in truth and rational objectivity. They are concerned with exploring and expressing the various ways in which we experience the world, interrupting, reframing and creatively seeking alternatives (see Baker and Gigliotti 2006), with many artists actively encouraging multiple interpretations of their work (Weintraub 2003). Ede (2005, p. 42) synthesizes this difference between art and science:

Compared with the cool rationalism of science with its material belief in wholeness, the theories employed by thinkers in the arts and humanities seem part of a playful circular game in which the truth is never to be privileged in one direction or another and is always out of reach.

There should be no getting away from the fact that a scientific attitude and an artistic imagination, with its playful, often metaphorical and abstract ways of thinking and communicating, can be very different. This does not mean, however, that they are completely incongruous. As Bright (2000, p. 140) contends within the context of contemporary art practice: "the quest for simplicity on the part of science and the delight in complexity on the part of art are incompatible although each side can learn from the other". Indeed, art may be more successful at engaging with science because of the expectation for art to be playful, challenging and subversive in a way that opens up opportunities for discussion (Calvert and Schyfter 2016). Wilson (2010) even argues that art and science can no longer survive in isolation from one another, either in terms of public support or in the production of knowledge. Whilst art - like science - takes many forms and has many processes, fundamentally it is a way of thinking and making connections, a way of communicating and a way of challenging. When freedom of expression is used as a political tool, art and artists have "come to occupy a privileged and enduring place in society [...] mobilising ideas and people to support or usurp powerful actors and systems" (Phillips 2008, p. 75). As practice, 
art - again, in a similar vein to science - can offer answers and pose new questions about how we experience and understand both the world around us and ourselves.

For evidence of their mutual interests, one needs only to examine the emergence of collaborative art and science initiatives since the 1990s as common ground whereby the two cultures have come (and worked) together ${ }^{8}$. Creative forms of public engagement with science operate within what Kinchy and Kleinman (2003) describe as the tension between the routine, conforming, and deep-rooted disciplinary desire for scientific purity and the pressure to demonstrate social relevance and utility. Science - the dialogical approach to communication tells us - is not done in a vacuum, it is part of society and scientists need to be open to and respond to the multiple perspectives and various ways in which developments in science are interpreted, accepted, and appropriated (see Irwin and Wynne 1996; Miller 2001; Horlick-Jones et al. 2007). Simply put, publics are not empty vessels ripe for filling. They already have existing beliefs, attitudes, alliances and ways of knowing. The colonisation therefore of this different type of 'third culture' by artists working with scientists to engage with scientific ideas and interests, once seen to be the domain of just scientists, is now commonplace (see Webster 2005). Through opening up the scientific process to artists, there is the opportunity to re-frame, reflect, re-imagine and re-purpose science. This creative wandering can also capture a perspective, or way of thinking, that has been forgotten, overlooked or pushed aside by science: a viewpoint other than that which surfaces solely from the laboratory.

\section{Translating Psychiatric Genetics: From Bench to Brain}


Over the past 25 years, UK science communication initiatives and public engagement with science and technology programmes have profited from the close relationship that art and artists have with different publics and communities. Formal support and funding, as well as more grass-roots encounters persist throughout the UK. The Wellcome Trust, a major British biosciences funding body, for example, continues to fund such collaborative endeavours, while 2017 sees the opening of Science Gallery London, part of a global initiative that promises to connect the arts, science and health to "inspire the next generation of creative thinkers" (Science Gallery 2016). This alliance though is more problematic when the science in question is psychiatric genetics. Though there is a long trail of work in the area of 'art and mental health', this often comes under the guise of art therapy or the promotion of health and wellbeing through creativity (Schmid 2005). There is much less work fostering an open dialogue about aspects of the diagnosis, causation and treatment of psychiatric conditions with public groups. Expressed frankly, psychiatric genetics has had a troubled relationship with the public (Smith 2008). Furthermore, the contested nature of psychiatry (Foucault 1986; Conrad and Barker 2010; Hacking 2000), the historical controversies within genetics (Kerr and Shakespeare 2002), and bad media experiences (Dreaper 2010) have added to scientific researchers' concerns that involvement with the arts might consolidate and perpetuate the perception that psychiatric genetics is a less scientific area of medicine. Nonetheless, psychiatric genetics research critically depends on an increased awareness and support of its research in order to attract funding and to raise its status as a discipline. Publics such as patients and research study controls are also resources necessary to do big population studies like psychiatric genetics research (Lewis and Bartlett 2015).

It is important to stress here that the history and politics of the specialisms of psychiatry and genetics has produced a very different landscape of opportunities and risk in public 
engagement imagined by psychiatric geneticists than that anticipated by, say, theoretical physicists. Engaging publics with the topic of mental health clearly involves a great deal more than simply communicating concepts clearly and effectively. Like much work on science communication proposes, it is also about framing, trust and epistemic hierarchy (Jasanoff 2003; Nisbet 2009). Of particular concern to psychiatric genetics is that public engagement with mental health requires an astute awareness of the complex power dynamics between experts and publics because of the inherent emotional resonance and contested nature of the subject matter. Advice arising from the public engagement of other emotive, and sometimes hostile, socio-scientific issues related to human behaviours, such as climate change, is to recommend that scientists do not avoid engaging with the public but that they should be aware that regaling facts is not enough, and that deeper human traits and feelings contribute to the subjective lens through which information is processed (Revkin 2011; Roeser 2012). Other social attitudes relevant to the communication of mental health research includes aspects often captured by the term stigma and, against this background, psychiatric geneticists feel that public engagement is a way to tackle not only stigma attached to mental illness, but also stigma attached to biological psychiatry itself (Lewis and Bartlett 2015). These issues of expertise, trust, power, diagnostic contestation, and stigma contribute to the tensions that can arise during the communication of psychiatric genetics research.

In order to explore the ways in which art can buffer potential clashes between psychiatric geneticists and publics, we endeavoured to engage with a wide spectrum of public groups. Embarking on our public engagement arts project, we were originally told not to 'scare the horses' and 'not in front of the children' by psychiatric geneticists at The Centre acutely aware of these complex dynamics and the ways in which their field is perceived. In 2011, despite some dissenting voices, we began to collaborate as social scientist and artist. Lines of 
enquiry within the artworks included laboratory practice, metaphors of genetics, geneenvironment interaction, the collaborative nature of large-scale genomic research, and the hopes and expectations of psychiatric genetics research. Some of the artworks, for instance, centred on aspects of 'big biology' (Bartlett 2008; Hilgartner 2013), which in the case of psychiatric genetics, is characterised by the necessarily large-scale collaborative patient studies that examine DNA from blood samples in relation to information provided in patient surveys. Large scale painting 'Big Science I', art installation 'Big Science II' and interactive digital artwork 'Disturbing the Blueprint' all incorporated elements that invited the public to participate, interact, and contribute either through the making of small components of the artwork or through direct bodily interaction, for example, by making a sound into a microphone that disturbed an edited image of themselves. A playful and seemingly trivial but surprisingly successful participatory act was the making and contribution of small blood red wire figures, used as the starting point for the painting 'Big Science I' and incorporated into the installation 'Big Science II'. Over 200 people contributed wire figures and this participation stimulated conversations about the scientific content of the artworks. 

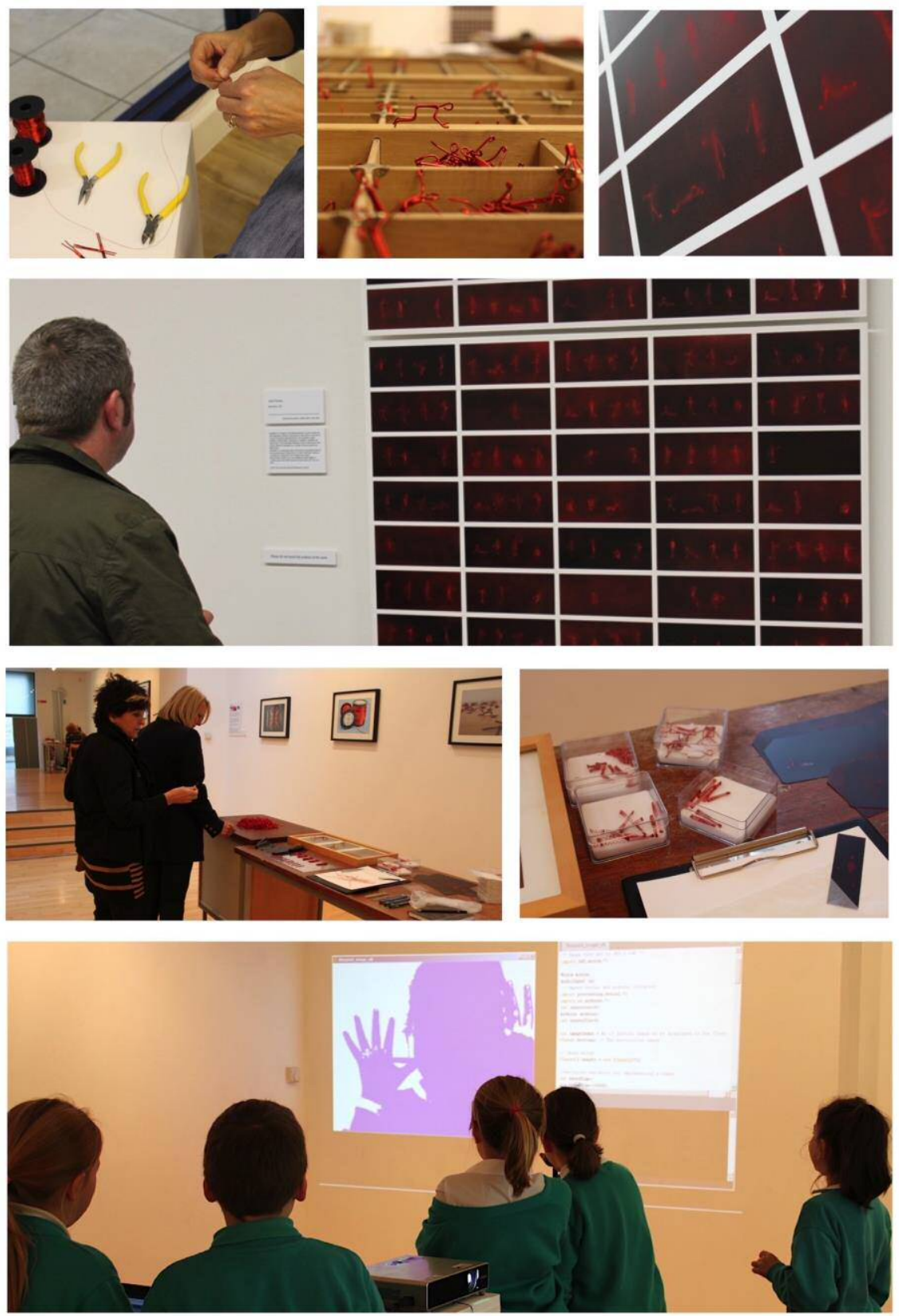

Big Science I, Big Science II and Disturbing the Blueprint

Although these were primarily object-based artworks, they fulfilled the function of what Kester (2004) refers to as 'conversation pieces'. Whilst one perspective is that these artworks served as icebreakers ${ }^{9}$, encouraging participation and discussion between the artistic work, the viewer and the subject matter; another perspective from socially engaged art practice is that the conversation and social engagement itself becomes the work of art (Helguera 2011). Careful consideration of the level of public participation is important to enable meaningful 
experiences and communication between individuals, and also to encourage publics to contribute and not to simply stand back as passive recipients. As Thomas (2012, p. 19) states: "recognising the importance of the public voice is vital for the public engagement of science but creating the right space for the public to feel they can contribute to the conversation can be a challenge". The motivation for this trialogue (see Anderson et al. 2010 ${ }^{10}$ ) - the expert, the public and the artwork - arises from observing that people are much more likely to instigate a conversation or participate in a discussion whilst in the role of creative participant, actively doing, rather than passively observing.

Other artists were invited to contribute to the growing conversation and the work took on a curatorial aspect, seeking out new perspectives and connections but always with the focus on public dialogue. We developed and organised two public engagement exhibitions called Translation: From Bench to Brain in 2011 and How The Light Gets In in 2013 that moved developments in psychiatric genetics and mental health out of the laboratory and into the public arena. These two exhibitions alone attracted around 1000 attendees. Academic speakers at public talks held within the exhibition spaces were impressed at how engaged and eager those that attended were to ask questions. Combining these well-attended academic presentations with smaller discussion sessions, creative workshops, music events, and poetry sittings, the gallery drew in particular publics who, we noticed, were comfortable with traditional art gallery spaces. Experimenting with different places and spaces of dialogue to attract new publics, the work expanded into empty shops in the centre of town, domestic spaces, a church, online interactions, and a yearlong series of art residencies, exhibitions and events in a large disused attic of a mental health charity.

Throughout these encounters between various lay public groups, scientists, medical students, 
social scientists and artists, we constantly sought new, creative and pan-disciplinary ways to both communicate and connect the varied understandings of the mind. Art and its use of metaphor, we maintain, provide the opportunity to re-imagine and interrupt the boundaries and relationships between different (disciplinary) cultures and sources of knowledge and to break away from the familiar and the rehearsed. We now turn to a discussion on metaphor, before discussing our concept of the Buffer Zone.

\section{The Role and Rule of Metaphor in Science, Art and Communication}

The word 'metaphor' originates from the Greek word metaphora, meaning 'a transfer' (OED 1989). Classically, it has been widespread in the artistic specialisms, especially within writing and poetry, the interchangeable play on words regarded as a form of ornamental language removed from the everyday. An extension to understanding metaphor as a transfer is that of a puzzling but calculated borrowing. In this sense, two seemingly different concepts interact such that one disturbs the other and it is this disruption that results in the generation of new perceptions, knowledge, and meaning (Black 1962; Ricoeur 2008). Of relevance to this idea of disruption is the work of critical thinker Serres (1982), regarded as a traveller between the arts and the sciences. His thoughts on science communication are particularly interesting in this respect since he described three elements: (i) a message, (ii) a channel for transmitting the message, and (iii) the noise or interference that accompanies the transmission. The noise may make the reading of the message more difficult but the metaphor, regarded as noise, creates a tension that "calls for decipherment [...] that opens up such a fertile avenue of reflection" (Lechte 2008, p. 348). 
Metaphor is therefore a borrowing, a deviation, a transposition and a perplexity (Ricoeur 2008), but this is no longer considered to be merely linguistic decoration. Rather, it is a ubiquitous way of thinking and reasoning, a cognitive device for our creation of meaning and understanding (Lakoff 1993; Lakoff and Johnson 2003). By a process of surprise and disruption, it allows us to transcend literal thinking and begin to generate meaning through questioning the connections that have been made in the process of developing the metaphor. This questioning then instigates a shift within the process of how we understand concepts by relating them to our own experiences (Lakoff and Johnson 2003).

Science, of course, is not averse to using metaphor both within its ways of working and in how it is communicated. ${ }^{11}$ Brown (2003, p. 2), for example, has argued that, "much of what scientists do [...] is governed by metaphorical reasoning". He maintains that metaphor links the language of science to the underlying reality it strives to achieve. According to Ahmad (2006, p. 198): "scientists literally and metaphorically create a world of make-believe through a web of words - some borrowed, some invented, endorsing self-belief here and suppressing the beliefs of others there". Metaphors delivered to a wider public often do this by drawing on objects that are familiar in society (Hellsten 2008). An often-used example of the use of metaphors to make sense of and to communicate complex science is evident in the field of genetics (Keller 1995; Kay 2000; Wolfe 2001; Condit 2009; O’Riordan 2010) where phrases such as the genetic code, the gene machine, gene mapping, blueprints and the book of life are frequently used. Similarly, metaphors can be used to communicate genetic risk and susceptibility, as described to us by a leading psychiatric geneticist working at The Centre.

So, you know, you may have a number of risk factors, and then if you develop a certain amount of risk, you will tip the scales. So, you would say you are trying to get this idea of 
balance and an accumulation of risk actually getting you into the diseased state. I would use visual clues to help me do that, but most people understand it.

[Interview with Professor of Psychiatric Genetics]

Linking to everyday societal objects such as weighing scales enables metaphors to be more persuasive when scientists communicate their ideas of genetic susceptibility to the public, bridging scientific and popular discourse. Likewise, the artist, through the use of metaphor, of making connections and seeing the similar in the dissimilar to suggest and evoke rather than to state facts, may help publics find a way into discussing the science by inviting, rather than eradicating, uncertainty. Thomas's interactive computer artwork, 'Disturbing the Blueprint', on show in the exhibitions was a commentary on the use of metaphors within the history of genetics, and how those metaphors have been used to bridge temporary gaps in knowledge. Likening computer-programming code to the metaphor of the genetic 'code', the work also highlighted how the language and discourse of genetics was influenced in the 1950s by the growth in computing and information theory. Visitors to the art-spaces were invited to have their photograph taken to add to the growing collection of images within 'Disturbing the Blueprint'. We explained how computer code enabled noise from the surrounding environment, picked up by the microphone, to disrupt and discolour blue and white versions of the contributed images. Following this, visitors were invited to disturb their own image and those of others. This participatory process initiated a conversation about the historical developments in the originally proposed concept of a genetic blueprint and how our understanding of this is constantly evolving. 


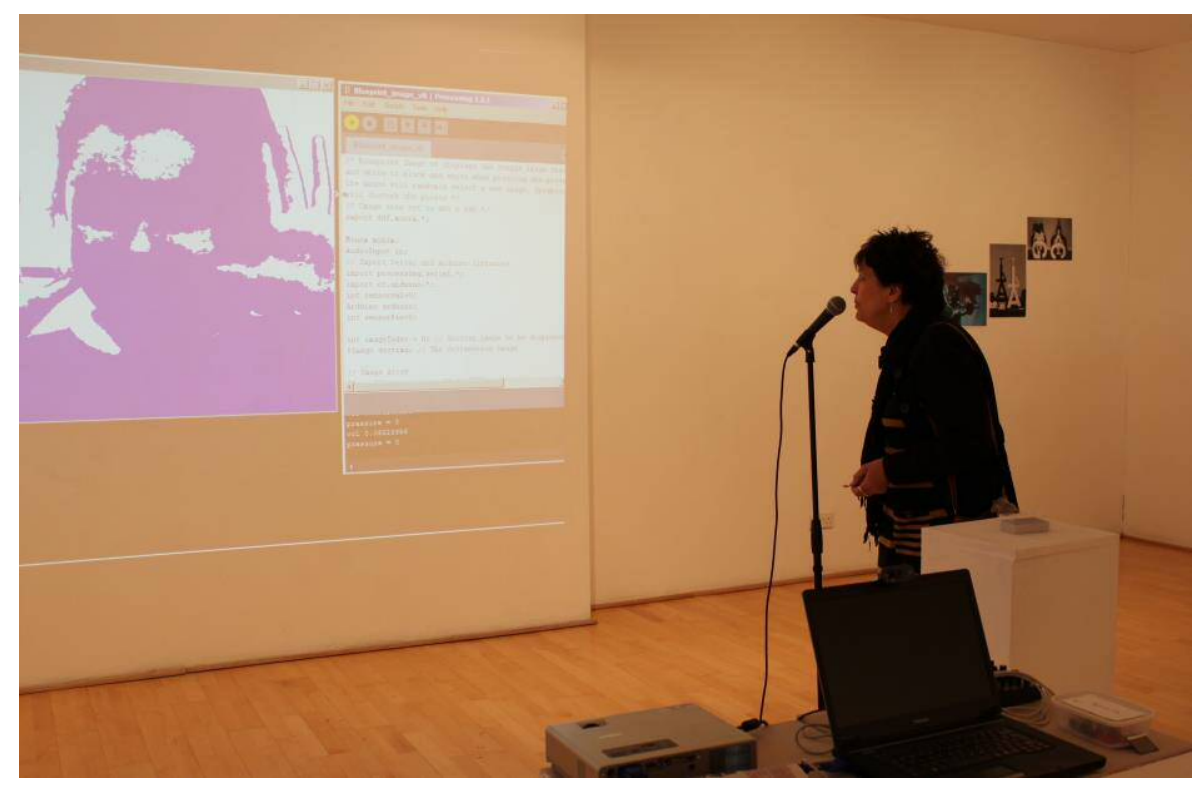

Disturbing the Blueprint

'Big Science I' and 'Big Science II' invited various publics to consider the unique contributions of individuals to genetic studies of psychiatric conditions and the collective efforts required to accomplish big population studies. These and other related artworks by Thomas evoked parallels between changes in creative media and developments in scientific technology that enabled reflections on the relationship between science and publics, and the timescale over which the generation of scientific knowledge takes place. By working with and experiencing these different media, public participants began to question, develop, and contribute meaning about the broader scientific references made within the artworks. In this participatory format, visual culture, and art and metaphor can provide a framework that encourages different groups to feel like they can contribute to the discourse of science, specifically because of the ambiguous nature of metaphors compared to standard forms of communication. Science, for example, is said to resist ambiguity and utilise very technical terminology when transferring and translating knowledge. Contemporary art, on the other hand, often invokes a purposeful elusiveness, employing tactics such as symbolism and metaphor (Hausman 1989; Collins and Evans 2007) in order to invite a response. 
From reflecting upon this case study, we suggest that propositions about future scenarios, ethical concerns, queries that go beyond current knowledge and questions aiming to reveal what might currently be concealed are given leverage by the ambiguity of metaphor. Ambiguity, although often the adversary to scientific clarity, provides an opportunity for farreaching questions and statements to not be considered out of place. However, enabling space, both physical and communicative, for boundaries to be transgressed can be a tempestuous negotiation that we argue art and metaphor has the potential to buffer.

\section{Buffer Zones between Experts and Publics}

Galison's Trading Zones concept is a metaphor taken from the economic transaction of goods between people from different cultures and applied to the sciences to describe a space where interdisciplinary research is instigated. Similar to a marketplace, a trading zone is a place where merchants from various hinterlands, speaking different languages, come together to form alliances, hammer out deals and exchange goods.

A Buffer Zone, on the other hand, is an area of land that lies between two (or more) hostile regions. They are often neutral zones, sometimes designed for environmental purposes and help to mitigate conflict between regions by keeping them apart or or by uniting them. The word buffer also has several connotations. According to the Oxford English Dictionary (OED 1989), to buffer has at least three actions specific to (i) everyday use, (ii) to chemistry and (iii) to computing.

verb: buffer 
- to lesson or moderate the impact of something or form a barrier between incompatible or antagonistic people or things

- to treat with a solution which resists changes in $\mathrm{pH}$ when acid or alkali is added to it

- to store (data) in a temporary memory area while it is being processed or transferred

(OED 1989)

In modern talk, 'to buffer' is used in both computing and railway parlance. It often refers to the display of pre-loaded content to alleviate an interrupted video streaming on the web, allowing the user to continue viewing. It is also used in reference to the buffer-and-chain coupling system on the railway networks. Attached to the end of carriages with shock absorbing pads, trains and wagons are brought safely into contact with one another via this arrangement. Finally, in the same workplace, the term describes a barrier, preventing trains running off track.

Each of these meanings could easily be used to describe the various ways in which artworks have agency within the public engagement of psychiatric genetics. Conversations between psychiatric geneticists and publics can travel in non-linear and divergent directions, moving from topic to topic, from matter of concern to matter of concern, attempting to escape, running out of steam and sometimes de-railing. This requires some repair work, but too much meddling and managing and those that attend may wish to use an alternative platform to express their views or, worse still, retreat back to their original stations. Here, when we talk about the Buffer Zone in relation to our art initiatives, we are not solely talking about the physical space that the artworks inhabit but also the less tangible space in which conversation turns to matters of concern, and the point at which the conversation begins to break down. Figures 1 to 6 show how we have developed the concept of the Buffer Zone beginning with 
'head-on' forms of science communication through to the various features of public engagement within either a typical art-space such as a gallery or less mainstream spaces in which artworks take place, both designated by the term (art)space.

Public engagement with science is "an often messy and contradictory business where dilemmas and paradoxes abound" (Irwin 2014, p. 74). For example, publics can come into conflict with scientific experts on issues such as agricultural biotechnology, nanotechnology or fracking. Issues of authority and power, as well as differences in outlooks, expertise and life experiences can lead to clashes between different groups and collectives during these more head-on forms of science communication and interactions. ${ }^{12}$ Figure 1 represents a scenario typical of many public 'dialogue' events whereby the scientific experts are positioned and privileged in a way that can create a sense of opposition with those attending the event, such as in a panel talk or a formal presentation.

\section{Key to figures 1-5}

(5) 1 (1) People of various socio-demographic characteristics

- Scientists from various disciplines

A Artist, curator or facilitator

Boundary of a tangible visible nature, e.g. physical wall

----. Boundary of an intangible nature, e.g. limit of conversation, imagination

$\longrightarrow \quad$ Focus of attention or direction of travel 
Fig. 1 Head-on forms of science communication

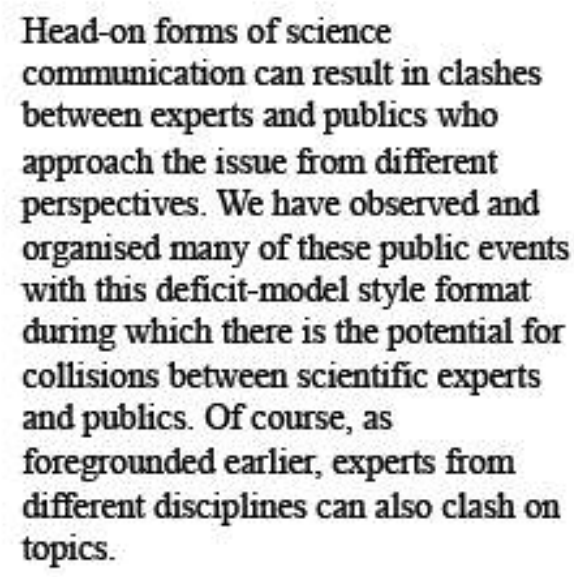

Head-on forms of science communication can result in clashes between experts and publics who approach the issue from different perspectives. We have observed and organised many of these public events with this deficit-model style format during which there is the potential for collisions between scientific experts and publics. Of course, as foregrounded earlier, experts from topics.

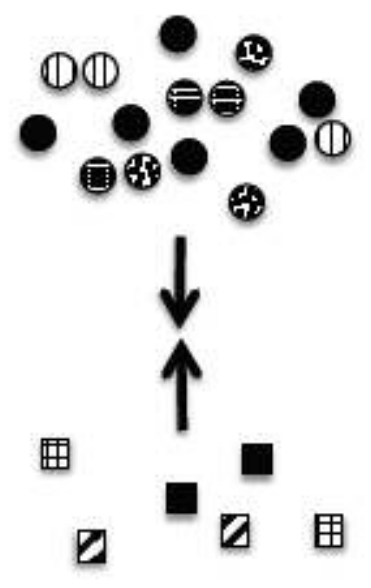

Interactional and behavioural norms of when and how a public 'audience' is allowed to contribute means that agency is privileged to the invited speakers and conflict emerges from the attendees' struggle to be heard (Davies 2011). Occasionally, this manifests itself as the ignoring of the ceremonial order of turn-taking and other public event etiquettes, signifying a rejection of this kind of format and its inherent power structures. Therefore, aside from clashes arising because of the subject matter of psychiatric genetics, there are generic factors related to the format of an event that can induce skirmishes.

Attention can be directed away from the confrontational nature of these head-on forms of science communication through artworks that can open up opportunities for reflection and conversation (see Figure 2). This is not to avoid challenges, but is to mitigate unnecessary confrontation. Whilst a lack of open conflict at public engagement events has been interpreted by some as a submissive but complicit alliance, resulting in friendly unchallenging interactions (Kerr et al. 2007), this does not mean that conflict is always necessary for meaningful and effective dialogue. 
Fig. 2 Opportunities for conversation

Focusing on the artwork creates space (both physical and temporal) for reflection and provides opportunities for conversations to begin and/or continue. Here, the artworks function something like a boundary object, connecting multiple worlds (Star and Griesemer, 1989).

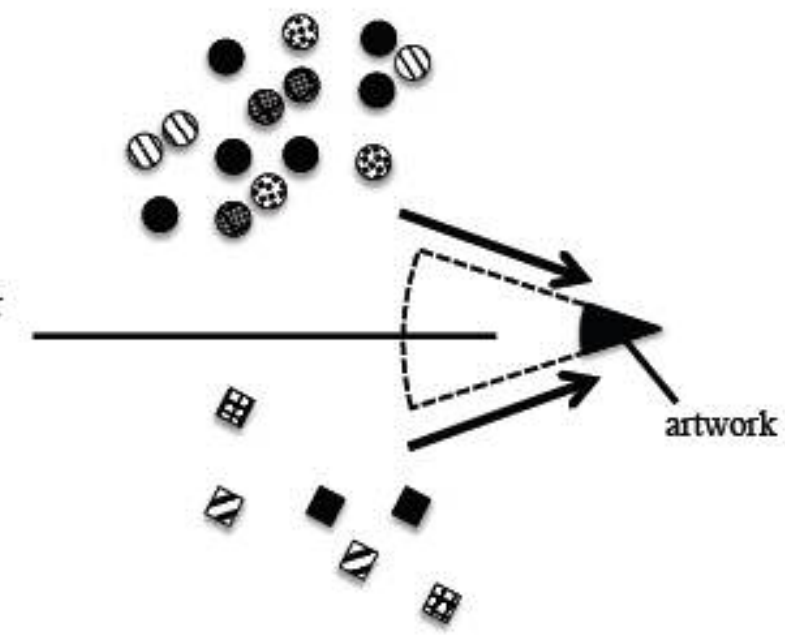

As we have found when using artworks to foster dialogue at various public engagement events, the metaphorical references often prompted people to begin a process of questioning, firstly to make meaning of the artwork, and subsequently the science. In the act of making, contributing and experiencing artworks, metaphor offers alternative imaginings in order to understand one experience in terms of another, what Lakoff and Johnson (2003) refer to as imaginative rationality. Different artworks within a public exhibition will inevitably instigate various degrees of reflection and conversation depending on a combination of the artistic agency and metaphorical content, the scientific content, aspects of presentation, and personspecific sensibilities of the viewer. The amount of imaginative and reflective content will vary according to the interplay between the trialogue of artwork, scientific content and participatory onlooker (see Figure 3). 
Fig. 3 The multifaceted content of artworks

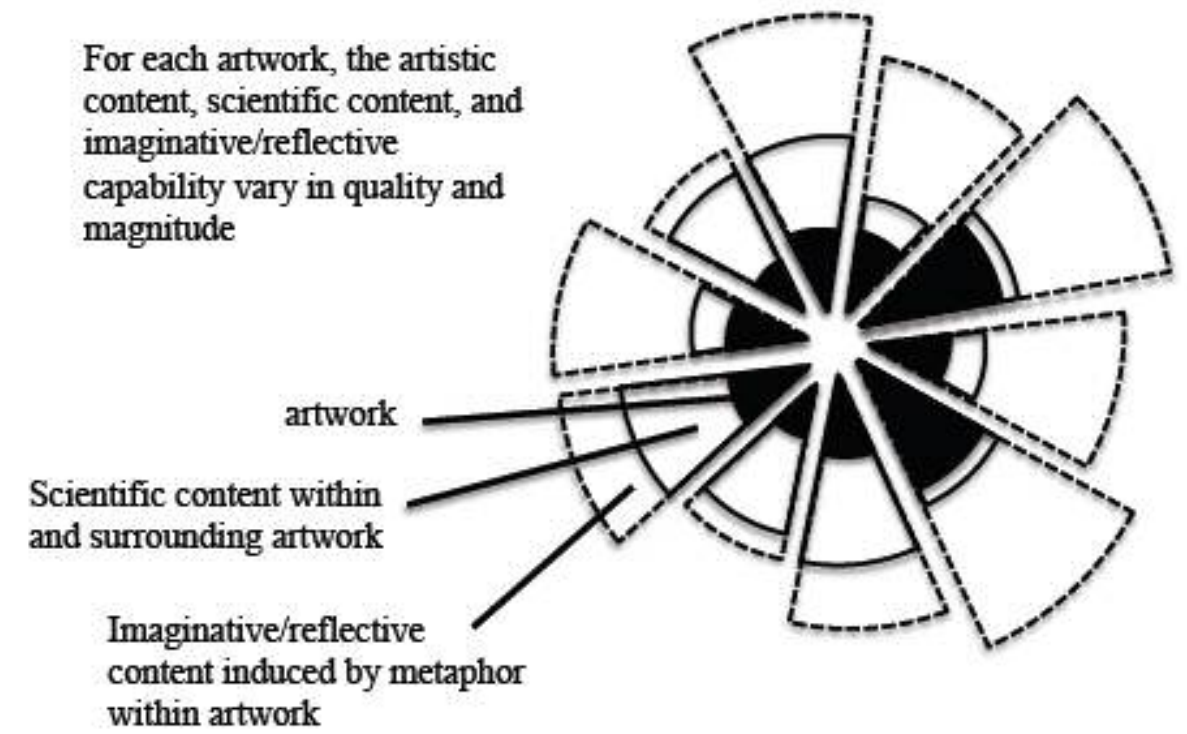

The scientific content related to an artwork may be embedded within the piece or it may surround it such as in information panels or accompanying academic talks. As depicted in Figure 4, engagement can be augmented via artist-led or curator-led talks and this we found facilitated conversations whereby the mixed audiences, including public groups, scientists, social scientists and so on, were able to respond to the artworks through the lens of their own experiences and expertise. 
Fig. 4 Walking and talking

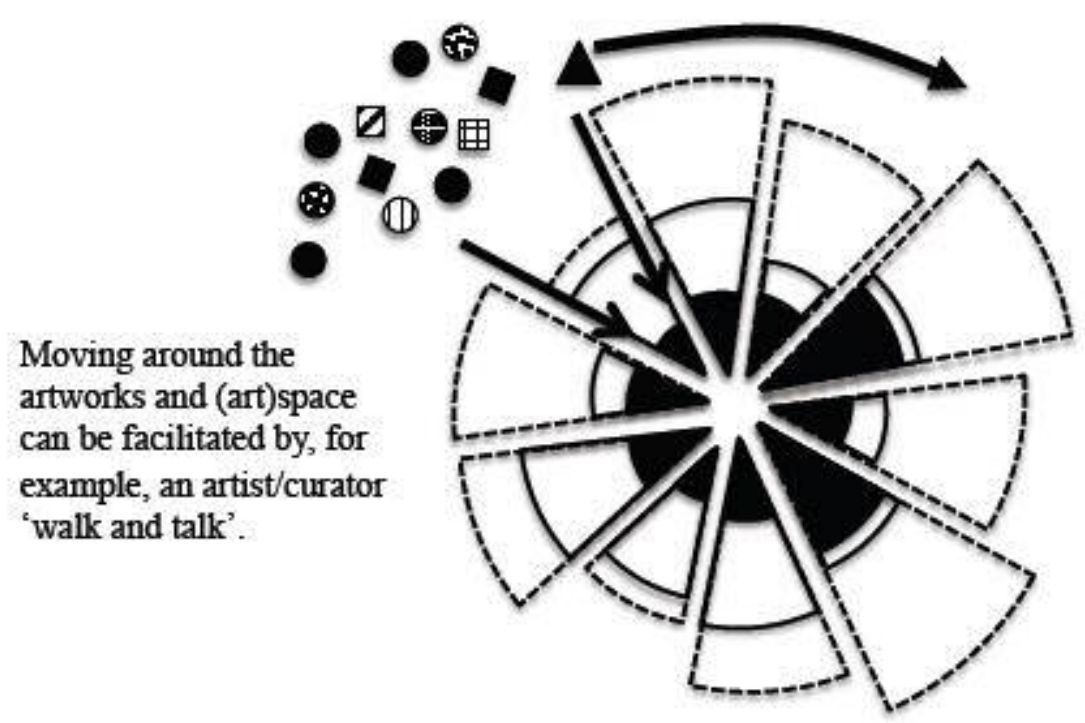

Walking and talking resonates with the idea of walking as a qualitative social research tool and means to knowledge whereby "it produces not a conventional interrogative encounter, but a collage of collaboration" (Anderson 2004, p. 260). Rather than walking through place, our 'walk and talk' through the (art)space was a wandering through the scientific disciplines, themes and issues relevant to psychiatric genetics. This journey and its talk is not always a friendly amble. However, potential pitfalls and potholes can be negotiated within the Buffer Zone (see Figure 5). 


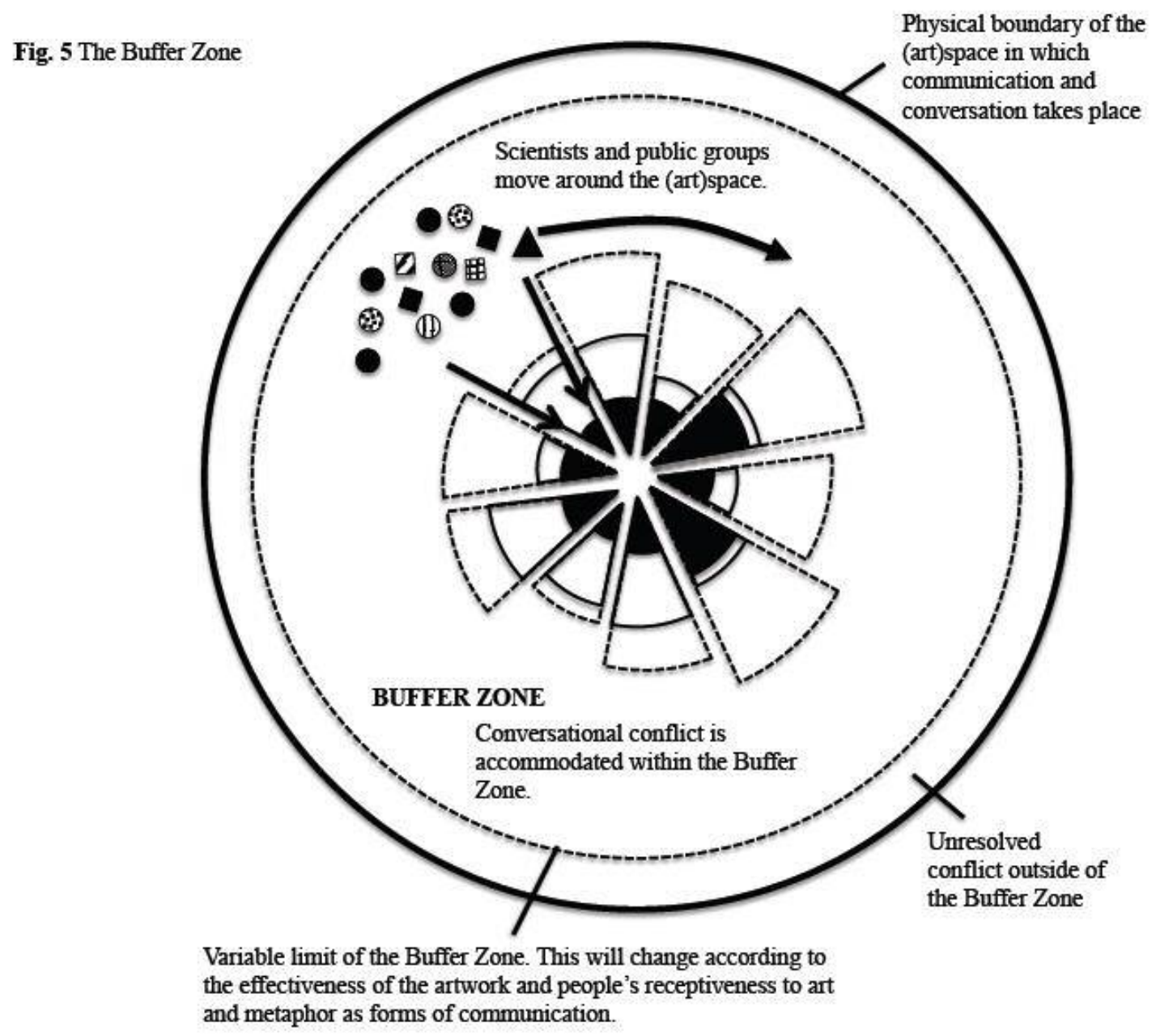

Although the architecture and physical limits of the (art)space can serve the purpose of a tangible observable boundary, the Buffer Zone and its limits also refer to the less tangible conversational and imaginative spaces that we occupy. Rather than viewing our arts activities as simply science communication then, in our public engagement programme we sought to explore how different perspectives and voices could come together within a framework that is at least one step removed from science, unafraid of controversy and multiple interpretations, familiar with evoking emotion, and embedded within ethical enquiry - in other words, art. We continued to examine the ways in which the complexity, troubles, hopes and fears within and surrounding psychiatric genetics might be aired in a less confrontational and more 
constructive way, aiming to keep people in the conversation, not losing them at the first clash or quarrel. We found that this dialogic and questioning standpoint, facilitated through the use of art and metaphor, afforded new framings in which public groups might feel they could engage with psychiatric genetics. This approach empowered people to air their fears such as to question how the translation of current research into therapeutic tools might 'alter' people with mental illness and how that vision for the future affects the way in which society perceives those people in the present. The idea of a modern-day eugenics remains a considerable concern to some people who feel that others are in control of their lives, while the perception of a knowledge-seeking but emotionless scientific approach was also raised as a concern. To this end, we found that people were not so interested in the science itself, much of it perceived as mundane lab-work and computer work. Instead, publics, and especially those with mental illness, were interested in what the science can do, and what impact it will have on people's lives. They were interested in the use of the science, its value and how it might be appropriated.

\section{Discussion}

The public engagement of psychiatric genetics and genomics is no easy task. Psychiatry's problematic past and genetics' as yet unfulfilled promises for a therapeutic future means there is the potential for conflict during public engagement events. These tensions can further inflame the usual considerations related to issues of trust, power dynamics and disciplinary boundaries of any science communication initiative. As foregrounded earlier, Mauss' observations of many decades previous, that exchange is intimately tied to those involved, highlights that discussions between psychiatric geneticists and publics involve much more 
than just the delivery of words, more than just sentiment too, what is said comes with the burden of unfinished business. This history (personal, professional and disciplinary) may originate from social factors related to perceived disparities in expertise and authority, but also past encounters between individuals and mental health professionals and researchers. Such unresolved concerns and transactions can be the root of any conflict and get in the way of what is said.

While, of course, the communication of developments in psychiatric genetics to publics should be much more than conveying information, facts and opinions clearly, the context for this is likely to be very different to interdisciplinary communication between specialisms and also very likely differs from the way other scientific specialisms communicate with their publics. That said, there are some parallels here between the public engagement of psychiatric genetics and other emotive socio-scientific subject matters that are dependent on human behaviour such as climate change. In examples such as these, there is a danger of swinging between the extremes of polite, unchallenging, almost subjugated discussion and dialogically destructive altercations.

We have therefore proposed that contemporary art within an adaptive and participatory public engagement programme provides a framework within which conflict can be mitigated so that constructive and meaningful dialogue takes place. Art can provide a framework that is comfortable with multiple interpretations and unafraid of controversy, provoking a willingness to challenge and question each other's perspectives and claims to knowledge irrespective of disciplinary roots and levels of expertise. In particular, we have extended Galison's concept of the Trading Zone to consider how an exchange of viewpoints can be 
facilitated through the use of art and metaphor. A conceptual, cognitive view of metaphor provides a useful mechanism to promote thinking about one thing in terms of another, to disturb the familiar and taken for granted ways of thinking, and to provoke a questioning mentality.

Bringing art and science together as part of a science communication initiative provided the opportunity to mollify conflict. Crucial to stress is that this mitigation was not to protect the science; it was to protect the conversation. By reflecting on five years of artistic public engagement activities using art and metaphor, both within mainstream and less traditional (art)spaces, we have developed the concept of the Buffer Zone. The artwork and associated metaphors enable conversations between scientists and publics to begin and to be maintained. It absorbs the head-on collision of aggressive questioning and enables just enough space so that potential conflict is ameliorated sufficiently to bring the conversation back to one that is constructive. If Galison $(1997,2010)$ uses the concept of Trading Zones to describe a place where scientific cultures and epistemes come together to forge alliances, Buffer Zones are spaces that recognise the differences in power between two (or more) cultural groups (see also Collins et al. 2010). It is a term that recognises the differences in the understanding of and relationship with the subject matter at hand and the importance that conversations do take place between groups that are often uneasy and unsteady in one another's company, enabling all the various positions to be heard, and not losing people at the first hint, or immanent fear, of discord.

Those involved in psychiatric genetics research might feel that engaging with these 'social' issues is to step out of their 'comfort zone', less a foot into a foreign land and more a jump from solid ground into wide, open oceans. Important to stress is that the concept of the Buffer 
Zone carries out work in both directions. It helps keep publics in the conversation, but also sanctions scientists to work with other disciplines to confront some of the social and ethical concerns and not to shy away from, to use another metaphorical warning from The Centre, 'airing their dirty linen in public'.

To conclude, we have reflected on how the scientific specialism of psychiatric genetics can re-connect with society through artistic work. Based on our wide range of experiences and observations within the public engagement of psychiatric genetics, our concept of the Buffer Zone proposes a way of working with unpredictable and divergent forms of intercultural communication within controversial and emotive science. The Buffer Zone protects the discussion of potentially sensitive and threatening topic areas from being aborted due to conflict, enabling groups to negotiate perceived battlegrounds rather than erecting old and new barricades.

\section{References}

Ahmad K (2006) Metaphors in the languages of science? In: Gotti M, Giannoni DS (eds) New trends in specialized discourse analysis. Lang, Bern, p 197-220

Anderson J (2004) Talking whilst walking: a geographical archaeology of knowledge. Area $36(3): 254-261$

Anderson JM, Adey P, Bevan P (2010) Positioning place: Polylogic approaches to research methodology. Qualitative Research 10(5):589-604

Baker S, Gigliotti C (2006) We have always been transgenic. AI \& Society 20:35-48 
Bartlett A (2008) Accomplishing sequencing the human genome. Dissertation, Cardiff University

Bennett DJ, Jennings RC (2011) Successful science communication. Cambridge University Press, Cambridge; New York

Black M (1962) Models and metaphors. Cornell University Press, New York

Braidotti R (2013) The Posthuman. Polity Press, Cambridge

Bright R (2000) Uncertain entanglements. In: Ede S (ed) Strange and charmed: Science and the contemporary visual arts. Calouste Gulbenkian Foundation, London, p 120-143

Brown TL (2003) Making truth: Metaphor in science. University of Illinois Press, Illinois

Burmeister M, McInnis MG, Zöllner S (2008) Psychiatric genetics: progress amid controversy. Nature Reviews Genetics 9(7):527-540

Calvert J, Schyfter P (2016) What can science and technology studies learn from art and design? Reflections on 'Synthetic Aesthetics'. Social Studies of Science. 
Caspi A, Moffitt TE (2006) Gene-environment interactions in psychiatry: joining forces with neuroscience. Nature Reviews Neuroscience 7(7):583-590

Cole S (1983) The hierarchy of the sciences. American Journal of Sociology 89:140-165pa

Collini S (1993) Introduction to C.P. Snow, The two cultures. Cambridge University Press, Cambridge

Collins HM (2011) Language and practice. Social Studies of Science 41(2):271-300

Collins HM (2014) Are we all scientific experts now? Polity Press, Cambridge

Collins HM, Evans R (2007) Rethinking expertise. University of Chicago Press, Chicago

Collins HM, Evans R, Gorman ME (2010) Trading zones and interactional expertise. In:

Gorman ME (ed) Trading zones and interactional expertise: Creating new kinds of collaboration. The MIT Press, Cambridge, MA and London, p 53-70

Condit CM (2009) Dynamic feelings about metaphors for genes: implications for research and genetic policy. Genomics, Society and Policy 5(3):1-15

Conrad P, Barker KK (2010) The social construction of illness: key insights and policy implications. Journal of Health and Social Behaviour 51(1 suppl):S67-S79 
Costache ID (2012) The art of understanding art: A behind the scenes story. WileyBlackwell, Chichester, West Sussex, UK

Davies SR (2011) The rules of engagement: power and interaction in dialogue events. Public Understanding of Science 22(1):65-79

Davies S, Horst M (2017) Science Communication: Culture, Identity and Citizenship. London: Palgrave MacMillan.

Dreaper J (2010) New study claims ADHD has genetic link. British Broadcasting Company [BBC]. Available via www.bbc.co.uk/news/health-11437079. Accessed $10^{\text {th }}$ October 2016

Duarte T (2013) Expertise and the fractal model: Communication and collaboration between climate change scientists. Dissertation, Cardiff University

Ede S (2005) Art and science. I. B. Tauris, London; New York

Fleck L (1935) Genesis and development of a scientific fact, 1981 edn. University of Chicago Press, Chicago

Foucault M (1986) The birth of the clinic: An archaeology of medical perception. Routledge, London 
Galison P (1997) Image and logic: A material culture of microphysics. University of Chicago Press, Chicago

Galison P (2010) Trading with the enemy. In: Gorman M (ed) Trading zones and interactional expertise: Creating new kinds of collaboration. The MIT Press, Cambridge, MA and London, p 25-52

Galison P, Stump DJ (1996) The disunity of science: Boundaries, contexts, and power. Stanford University Press, Stanford

Garneau D (2008) Art, science and aesthetic ethics. In: Caulfield S, Caulfield T (eds) Imagining science: Art, science, and social change. The University of Alberta Press, Alberta, p $27-29$

Gieryn TF (1983) Boundary-work and the demarcation of science from non-science: strains and interests in professional ideologies of scientists. American Sociological Review 48(6):781-795

Gieryn TF (1999) Cultural boundaries of science: Credibility on the line. University Chicago Press, Chicago

Glinkowski P, Bamford A (2009) Insight and exchange: An evaluation of the Wellcome Trust's sciart programme. Wellcome Trust, London. Available via www.wellcome.ac.uk/sciartevaluation. Accessed 19 June 2016

Gould SJ (2003) The hedgehog, The fox and the magister's pox. Harmony Books, New York 
Gregory J, Miller S (1998) Science in Public: Communication, culture and credibility. Basic Book, Cambridge, MA

Hacking I (1994) Styles of scientific thinking or reasoning: A new analytical tool for historians and philosophers of the sciences. In: Gavroglu K, Christianidis J, Nicolaidis E (eds) Trends in the Historiography of Science. Springer, Dodrect, p 31-48

Hacking I (2000) The social construction of what? Harvard University Press, Cambridge, MA

Hall JR (1999) Cultures of inquiry: From epistemology to discourse in sociohistorical research. Cambridge University Press, Cambridge

Hausman CR (1989) Metaphor and art: Interactionism and reference in the verbal and nonverbal arts. Cambridge University Press, Cambridge

Helguera P (2011) Education for socially engaged art: A materials and techniques handbook. Jorge Pinto Books, New York

Hellsten I (2008) Popular metaphors of biosciences: bridges over time? Configurations $16(1): 11-32$

Hilgartner S (2013) Constituting large-scale biology: building a regime of governance in the early years of the human genome project. BioSocieties 8:397-416

Hoffmann R (2002) On poetry \& the language of science. Daedalus 131(2):137-140 
Holliman R, Whitelegg E, Scanlon E, Thomas J (eds) (2009) Investigating science communication in the information age: Implications for public engagement and popular media. Oxford University Press, Oxford

Holmberg T, Ideland M (2016) Imagination laboratory: making sense of bio-objects in contemporary genetic art. The Sociological Review 64(3):447-467

Holmwood J (2010) Sociology's misfortune: disciplines, interdisciplinarity and the impact of audit culture. The British Journal of Sociology 61(4):639-658

Horlick-Jones T, Walls J, Rowe G, Pidgeon N, Poortinga W, Murdock G, O’Riordan T (2007) The GM debate: Risk, politics and public engagement. Routledge, Abingdon

Horst M (2013) A field of expertise, the organization, or science itself? Representing research in public communication. Science Communication 35(6):758-779

Irwin A (2014) From deficit to democracy (re-visited). Public Understanding of Science 23(1):71-76

Irwin A, Wynne B (eds) (1996) Misunderstanding Science? Cambridge University Press, Cambridge

Jasanoff S (2003) Breaking the Waves in Science Studies. Social Studies of Science $33(3): 389-400$ 
Joseph J (2006) The missing gene: Psychiatry, heredity, and the fruitless search for genes. Algora Publishing, New York

Kay LE (2000) Who wrote the book of life?: A history of the genetic code. Stanford University Press, Stanford, California

Keller EF (1995) Refiguring life: Metaphors of twentieth-century biology.

Columbia University Press, New York; Chichester

Kerr A, Shakespeare T (2002) Genetic politics: From eugenics to genome. New Clarion Press, Cheltenham

Kerr A, Cunningham-Burley S, Tutton R (2007) Shifting subject positions experts and lay people in public dialogue. Social studies of science 37(3):385-411

Kester GH (2004) Conversation pieces: Community and communication in modern art. University of California Press, Berkeley

Kinchy AJ, Kleinman DL (2003) Discursive and organisational orthodoxy on the borders of ecology and politics. Social Studies of Science 33(6):869-896

Knorr Cetina K (1999) Epistemic cultures: How the sciences make knowledge. Harvard University Press, Cambridge, Massachusetts 
Lakoff G (1993) The contemporary theory of metaphor. In: Ortony A (ed) Metaphor and thought. Cambridge University Press, Cambridge, p 202-251

Lakoff G, Johnson M (2003) Metaphors we live by. University of Chicago Press, Chicago; London.

Lave J, Wenger E (1991) Situated learning: Legitimate peripheral participation. Cambridge University Press, Cambridge.

Lechte J (2008) Fifty key contemporary thinkers: From structuralism to post-humanism, 2nd edn. Routledge, London

Lewis J, Bartlett A (2015) How UK psychiatric geneticists understand and talk about engaging the public. New Genetics and Society 34(1): 89-111

Lewis J, Bartlett A, Atkinson, P (2016) Hidden in the middle: culture, value and reward in bioinformatics. Minerva 54(4): 471-490

Lewis J, Bisson S, Swaden-Lewis K, Reyes-Galindo L, Baldwin, A (2017) Cardiff sciSCREEN: a model for using film screenings to engage publics in university research. Research for All 1(1): 106-120

Mauss M (1969/1925) The Gift. Routledge and Paul Kegan, London.

Miller S (2001) Public understanding of science at the crossroads. Public Understanding of Science 10(1):115-120 
Nisbet M (2009) Communicating climate change: why frames matter for public engagement. Environment: Science and Policy for Sustainable Development 51(2):12-23

OED: Oxford English Dictionary (1989) In: Oxford University P (ed) Oxford English dictionary online, 2nd edn. Oxford University Press, Oxford

O’Riordan K (2010) The genome incorporated: Constructing biological identity. Routledge, London

Owen MJ, Cardno AG (1999) Psychiatric genetics: progress, problems, and potential. The Lancet 354:S11-S14

Phillips PWB (2008) Art and the governance of new technologies. In: Caulfield S, Caulfield T (eds) Imagining science: Art, science, and social change. University of Alberta Press, Alberta, p 27-29

Pinar WF, Reynolds WM, Slattery P, Taubman PM (2008) Understanding curriculum: An introduction to the study of historical and contemporary curriculum discourses. Lang, New York

Plomin R, Owen MJ, McGuffin P (1994) The genetic basis of complex human behaviors. Science 264(5166):1733-1739 
Popper KR (1994) The myth of the framework: In defence of science and rationality. Routledge, London

Propping P (2005) The biography of psychiatric genetics: from early achievements to historical burden, from an anxious society to critical geneticists. American Journal of Medical Genetics Part B (Neuropsychiatric Genetics) 136B(1):2-7

Revkin AC (2011) Tackling the climate communication challenge. In: Bennett DJ, Jennings RC (eds) Successful science communication: Telling it like it is. Cambridge University Press, Cambridge, p 137-150

Reyes-Galindo L (2014) Linking the subcultures of physics: virtual empiricism and the bonding role of trust. Social Studies of Science 44(5):736-757

Rheinberger H-J (2016) Culture and nature in the prism of knowledge. History of Humanities $1(1): 155-181$

Ricoeur P (2008) The rule of metaphor: The creation of meaning in language. Routledge, London

Roeser S (2012) Risk communication, public engagement and climate change: a role for emotions. Risk Analysis 32(6):1033-1040

Rowe G, Frewer LJ (2005) A typology of public engagement mechanisms. Science, Technology and Human Values 30(2):251-90 
Schmid T (2005) Promoting health through creativity: For professionals in health, arts and education. Whurr, London

Science Gallery London (2016) Available via https://london.sciencegallery.com. Accessed 19 June 2016

Serres M (1982) Hermes-literature, science, philosophy. Harari JV, Bell DF (eds) Johns Hopkins University Press, Baltimore

Shaffer E (1998) The third culture: Literature and science. De Gruyter, New York Shapin S (1984) Pump and Circumstance: Robert Boyle's literary technology. Social Studies of Science 14:481-521

Shapin S, Schaffer S (1985) Leviathan and the Air Pump: Hobbes, Boyle and the experimental life. Princeton University Press, Princeton

Smith MJ (2008) Public psychiatry: a neglected professional role? Advances in psychiatric treatment 14:339-346

Snow CP (1959) Two cultures. Cambridge University Press, Cambridge

Snow CP (1963) Two cultures: And a second look, 2nd edn. Cambridge University Press, Cambridge 
Star SL, Griesemer JR (1989) Institutional ecology, translations and boundary Objects: amateurs and professionals in Berkley's Museum of Vertebrate Zoology, 1907-39. Social Studies of Science 19(3):387-420

Stoltenberg SF, Burmeister M (2000) Recent progress in psychiatric genetics - some hope but no hype. Human Molecular Genetics 9(6):927-935

Storer NW (1967) The hard sciences and the soft: some sociological observations.

Bulletin of the Medical Library Association 55(1):75-84

Strathern M (2006) A community of critics? Thoughts on new knowledge. Journal of the Royal Anthropological Institute 12(1):191-209

The Royal Society (1985) The public understanding of science. Royal Society, London

Thomas J (2012) The art of public engagement. People \& Science, March, p 19

Webster S (2005) Art and science collaborations in the United Kingdom. Nature

Reviews/Immunology 5:965-969

Weingart P, Stehr N (eds) (2000) Practising interdisciplinarity. University of Toronto Press, Toronto 
Weintraub L (2003) Making contemporary art: How modern artists think and work. Thames \& Hudson, London

Wilsdon J, Willis R (2004) See-through science: Why public engagement needs to move upstream. DEMOS, London

Wilson S (2010) Art + science now. Thames \& Hudson, London

Wolfe A (2001) Essay review: ELSI's revenge. Journal of the History of Biology 34(1):183193

Wynne B (1992a) Public understanding of science research: new horizons or hall of mirrors? Public Understanding of Science 1(1):37-43

Wynne B (1992b) Misunderstood misunderstanding: social identities and public uptake of science. Public Understanding of Science 1(3):281-304

Yearley S (2005) Making sense of science: Understanding the social study of science. SAGE, London

\footnotetext{
${ }^{1}$ Braidotti (2013), for one, worries for the future survival of the humanities disciplines.
} 


\footnotetext{
${ }^{2}$ Throughout history, many prominent scientists have been aware of the importance of communicating with 'the public' and creating layperson audiences as a critical component of their scientific work (see Shapin 1984; Shapin and Schaffer 1985). Today, though, we are experiencing an institutional turn for scientists to engage in science communication and for engagement to move upstream (Wilsdon and Willis 2004).
}

${ }^{3}$ A disunified science is more vulnerable to public scrutiny when empirical matters become public interest or publically aired. A clear example of this was the polarised split between a clinical psychologist and a clinical psychiatrist over the perceived geneticisation of Attention Deficit Hyperactivity Disorder (ADHD). This debate peppered the front pages over the UK's broadsheet and tabloid papers in early September, 2010 (Dreaper 2010; Lewis and Bartlett 2015).

${ }^{4}$ From the 1920s the development of genetic research on complex human behaviours led to the merging of quantitative genetic approaches, such as genetic epidemiology, with the techniques of molecular genetics (Plomin et al. 1994; Owen and Cardno 1999). Relatively recently, this research has also incorporated neuroscience and bioinformatics in order to identify the biological mechanisms and functional pathways that affect behaviour and brain function (Caspi and Moffitt 2006; Burmeister et al. 2008).

${ }^{5}$ See, in particular, Gould (2003) who has focussed on the commonalities and affinities between the humanities and the sciences.

${ }^{6}$ Although, this has for some time been considered to be scientific ideology put to work for the purposes of creating boundaries around science to demarcate itself from non-science (Gieryn 1983).

${ }^{7}$ The deficit model assumed that publics' distrust of and disengagement with science was due to a lack of scientific understanding. Up until the mid 1990s, filling this deficit with scientific facts was considered by the scientific community to be the answer to improving the public's relationship with science (see Miller 2001).

\footnotetext{
${ }^{8}$ Even so, some sci-art collaborations, as they have been termed, have been criticised as artistically uninteresting (Ede 2005) or inauthentic (Glinkowski and Bamford 2009) precisely because circumstances have meant the artists were seen to be simply illustrating science and not engaging in real and meaningful dialogue with scientists.
} 
${ }^{9}$ Perceived like this, the artwork could also be described as a boundary object (Star and Griesemer 1989).

${ }^{10}$ Anderson (2010) uses the concept of the trialogue in the context of walking and talking methods and, in particular, the relationship between the researcher, the participant and the place where they are walking.

${ }^{11}$ Nowadays, the language of contemporary science is said to be under stress with words being used to characterise processes that on the surface appear indescribable (Hoffman 2002).

${ }^{12}$ See Wynne (1992b), Yearley (2005), and Wilsdon and Willis (2004) for examples of clashes between scientific experts and publics related to radioactive fallout in Cumbria, North England, the BSE crisis, genetically modified crops, and the Mumps Measles Rubella (MMR) vaccine. 